\title{
Left ventricular remodeling assessment in patients with anterior acute myocardial infarction treated with successful primary percutaneous coronary intervention: an observational study
}

\author{
Başarılı primer perkütan koroner girişim uygulanan anteriyor akut miyokart enfarktüslü \\ hastalarda sol ventrikülün yeniden şekillenmesinin değerlendirilmesi: Gözlemsel bir çalışma
}

Hatice Uslu, Nazmiye Cakmak', Melih Engin Erkan², Sevim Hacımahmutoğlu³, Sabire Yılmazt, Sevil Özkan ${ }^{5}$, Nurten Sayar'

Department of Nuclear Medicine, Faculty of Medicine, Istanbul Medeniyet University, Istanbul-Turkey

${ }^{1}$ Clinic of Cardiology, Siyami Ersek Cardio-Vascular Surgery Hospital, Istanbul-Turkey

${ }^{2}$ Department of Nuclear Medicine, Faculty of Medicine, Düzce University, Düzce-Turkey

${ }^{3}$ Clinic of Nuclear Medicine, Siyami Ersek Cardio-Vascular Surgery Hospital, Istanbul-Turkey

${ }^{4}$ Department of Nuclear Medicine, Cerrahpaşa Faculty of Medicine, Istanbul University, Istanbul-Turkey

${ }^{5}$ Clinic of Internal Medicine, Siyami Ersek Cardio-Vascular Surgery Hospital, Istanbul-Turkey

\section{ABSTRACT}

Objective: We aimed to analyze the left ventricular (LV) remodeling in patients treated with coronary intervention (PCI) in the acute phase of anterior myocardial infarction (MI) and to analyze the relationship between LV functional remodeling and residual viability in the infarct zone detected by thallium-201 (TI-201) imaging and echocardiography.

Methods: We designed an observational prospective cohort study including 30 patients ( 26 men, 4 women, mean age; $52 \pm 12$ years old) with acute anterior MI. Echocardiography and TI-201 imaging were performed in all patients three days and two months after PCI and left ventricular end-systolic volume (ESV), left ventricular end-diastolic volume (EDV), ejection fraction (EF) and summed redistribution score (SRS) were calculated. Paired samples t- test or Wilcoxon rank sign test for comparing continuous variables in dependent groups, Pearson correlation for testing relationship between continuous variables were used.

Results: Left ventricular function baseline values just after $\mathrm{PCl}$ and two months after $\mathrm{PCl}$ obtained by echocardiography and scintigraphy were statistically significant. Among patients $76.7 \%$ had an EF $\geq 0.50$ after the event. EDV and ESV values are significantly low when compared to values two months before. There was not any marked change in SRS in five patients. Polar maps were correlated with heart rate $(r=0.438$; $p=0.023)$, peak creatine kinase $M B(r=0.440 ; p=0.015)$ and troponin $(r=0.471 ; p=0.009)$ during acute MI.

Conclusion: Significant recovery in EDV, ESV and SRS values, and increase in EF two months after the infarction shows us substantial part of the remodeling process is completed in two months and TI-201 imaging is extremely effective in determining of salvaged myocardium.

(Anadolu Kardiyol Derg 2013; 13: 675-81)

Key words: Acute myocardial infarction, coronary intervention, thallium-201, echocardiography, viability

ÖZET

Amaç: Bu çalışmanın amacı, anteriyor miyokart enfarktüsünün (AME) akut fazında primer koroner girişim (PKG) ile tedavi edilen hastalarda sol ventrikül yeniden yapılanma sürecini, enfarkt alanında saptanan rezidüel canlılık ve sol ventrikül fonksiyonel yeniden yapılanma süreci arasındaki korelasyonu thallium-201 (TI-201) görüntülemesi ve ekokardiyografi ile araştırmaktı.

Yöntemler: Bu çalışma akut anteriyor miyokart enfarktüslü 30 hastanın (26 erkek, 4 kadın, yaş ortalaması; $52 \pm 12$ yıl) dahil olduğu gözlemsel prospektif bir kohort çalışmadır. PKG girişiminden üç gün ve iki ay sonra ekokardiyografi ve TI-201 görüntülemesi yapıldı. Sol ventrikül sistol sonu hacmi (ESV), sol ventrikül diyastol sonu hacmi (EDV), ejeksiyon fraksiyonu (EF) ve tüm hastaların toplam redistribüsyon skoru hesaplandı. Sayısal veriler bağımlı guruplarda karşılaşııılırken Paired samples t-test veya Wilcoxon rank sign test kullanıımıştır. Doğrusal ilişki araştırılırken Pearson korelasyon analizi kullanıldı. $P<0,05$ istatistiksel olarak anlamlı kabul edildi.

Bulgular: PKG'dan hemen sonra ve iki ay sonrası ekokardiyografi ve sintigrafi ile elde edilen değerler istatistiksel olarak anlamlıydı. Girişimden iki ay sonra hastaların çoğunda $(76,7 \%)$ EF $\geq 0,50$ olduğu gözlemlendi. Çalışmamızda EDV ve ESV değerleri iki ay öncesi değerlerle karşılaştırıldığında önemli derecede düşük bulundu. Ancak, 5 hastanın toplam redistribüsyon skorunda anlamlı bir değişim olmadı. Polar harita AME esnasındaki kalp hızı $(r=0,438 ; p=0,023)$, pik kreatin kinaz MB $(r=0,440 ; p=0,015)$ ve troponin । $(r=0,471 ; p=0,009)$ değerleri ile doğrusal ilişkili bulunmuştur.

Sonuç: PKG sonrası yeniden yapılanma sürecinde; EDV, ESV ve toplamı redistribüsyon skoru değerlerinde anlamlı azalma olması ve bazal EF değerlerinin artış göstermesiyle yeniden yapılanma sürecinin iki ay içerisinde önemli ölçüde tamamlanmış olduğunu, rest-redistribisyon TI-201 görüntülemenin kurtarılan canlı miyokart dokusunu saptamada son derece etkin olduğunu göstermiştir. (Anadolu Kardiyol Derg 2013; 13: 675-81)

Anahtar kelimeler: Akut miyokart enfaktüsü, koroner girişim, thallium-201, ekokardiyografi, canlılık

Address for Correspondence/Yazışma Adresi: Dr. Hatice Uslu, Medeniyet Üniversitesi Tıp Fakültesi, Eğitim ve Araşturma Hastanesi, Merdivenköy Poliklinikleri, Nükleer Tip Anabilim Dalı, Kadıköy, Istanbul-Türkiye Phone: +90 5324363976 Fax: +90216 $5666614 \mathrm{E}$-mail: uslusinav@hotmail.com

Accepted Date/Kabul Tarihi: 31.01.2013 Available Online Date/Çevrimiçi Yayın Tarihi: 28.08.2013

(C) Telif Hakkı 2013 AVES Yayıncillk Ltd. Stti. - Makale metnine www.anakarder.com web sayfasından ulașilabilit. (c) Copyright 2013 by AVES Yayıncilik Ltd. - Available on-line at www.anakarder.com doi:10.5152/akd.2013.192 


\section{Introduction}

Progressive damage or remodeling of the left ventricle (LV) can develop during the first months after the acute myocardial infarction (AMI) and have a negative influence on long term prognosis. The advantage of primary $\mathrm{PCl}$ have been ascribed to the achievement of early superior flow with significant larger myocardial salvage and improved survival (1).The presence of residual viability in the infarct area can favorably influence LV remodeling (2). The purpose of reperfusion therapy in patients with $\mathrm{AMI}$ is to achieve significant myocardial salvage and to limit the extent of irreversible tissue damage. Salvaged myocardium is precisely defined as the area between the initial field at risk for infarction and the final infarct size. Rest-redistribution thallium-201 (TI-201) single-photon emission computerized tomography (SPECT) imaging after the AMI is shown to be highly accurate for detection of myocardial salvage (3-6). TI-201 imaging has been used for the determination of infarct zone and the amount of salvage in patients treated with $\mathrm{PCl}$ in the acute phase and two months after myocardial infarction. Besides rest-redistribution TI-201 imaging, there are several nuclear medicine methods that display myocardial viability, such as stress-rest-reinjection TI-201, twenty-four-hour TI-201 imaging, F-18-fluorodeoxyglucose positron emission tomography, nitrate sestamibi imaging. $(7,8)$. Positron emission tomography has been considered as the gold standard for assessment of myocardial viability using metabolic tracer (7).

Similar studies examining myocardial salvage and LV functional remodeling have been published previously. Most of these studies compared one week and 6 months after $\mathrm{PCl}$ and used technetium-99m sestamibi (9-12). We want to compare the early ( 3 days) and late ( 2 months) period after $\mathrm{PCI}$ because we ignored the probability of early restenosis and consider that LV remodeling in 2 months post- $\mathrm{PCl}$ was almost near completed.

The aim of this study was to analyze the prevalence of LV remodeling in patients treated with $\mathrm{PCl}$ in the acute phase of an initial AMI and to analyze the relationship between LV functional remodeling detected by echocardiography and residual viability in the infarct zone detected by TI-201 SPECT imaging.

\section{Methods}

\section{Study design}

We designed an observational prospective cohort study to investigate the impact of $\mathrm{PCl}$ on LV remodeling using echocardiography and rest- redistribution TI-201 SPECT imaging.

\section{Study population}

This study included 30 consecutive patients ( 26 men, 4 women, mean age; $52 \pm 12$ years old) with first acute anterior myocardial infarction who were admitted to our emergency coronary care unit within 6 hours of the onset of symptoms and referred to the catheterization laboratory for urgent primary $\mathrm{PCl}$. Late presenters were not included in this study. The diagnosis of acute AMI was established by the presence of chest pain lasting more than 20 min associated with electrocardiographic changes (ST segment elevation of $\geq 2 \mathrm{~mm}$ in at least two contiguous leads in the same vascular territory) and increase in serum myocardial creatine kinase (IU/L) and peak troponin I $(\mathrm{ng} / \mathrm{mL}$ ) levels. The exclusion criteria included cardiogenic shock, cardiac muscle disease, significant valvular disease, hemodynamic instability, a history of coronary bypass surgery, ones that TIMI-3 circulation could not be provided, previous myocardial infarction and presence of a coronary artery other than left anterior descending artery more than $50 \%$ of which has already been stenosed.

\section{Study protocol}

Coronary angiography, $\mathrm{PCl}$ applications, MPS, echocardiography and biochemical investigations are methods applied to AMI patients for diagnosis, treatment and monitoring response to the treatment. The study protocol was approved by the local ethical committee. In addition to, signed informative patient consent form was received from all of the patients, separately for each intervention and imaging method that will be conducted.

\section{Echocardiography}

Two-dimensional echocardiography was performed in all patients three days and two months after $\mathrm{PCl}$. Using the Vingmed System 7 (Vivid 7, GE, Horten, Norway), two-dimensional images were obtained and left ventricular end-systolic volume (ESV), left ventricular end-diastolic volume (EDV) and ejection fraction (EF) of all patients were calculated utilizing modified Simpson method $(1,10,13)$.

\section{Rest-redistribution TI-201 S PECT myocardial perfusion scintigraphy}

Rest-redistribution TI-201 SPECT imaging was performed at day 3 of the acute event and two months after PCI. SPECT images of the study were obtained $20 \mathrm{~min}$ and 3 hours after the injection of TI-201 intravenously $(4,7)$. SPECT was performed using a large field of view gamma camera with a high-resolution parallel-hole collimator (Apex SRX Cardial, Elscint, Israel) rotated $180^{\circ}$ around the long axis of each patient. Thirty-six views, at each $5^{\circ}$ were obtained for 25 seconds from the $45^{\circ}$ left posterior oblique to the $45^{\circ}$ right anterior oblique projection. After correction for non-uniformity and center of rotation, images were reconstructed into long and short-axis cuts.

\section{Analyses of radionuclide images}

The SPECT images were divided into 17 segments: The shortaxis images were obtained at apical, middle and lower ventricular levels, and were divided into six segments (anteroseptal, inferoseptal, anterior, anterolateral, inferolateral, inferior). The apex of the left ventricle was assessed using a five-point scale system (0; normal uptake, 1 ; mildly reduced uptake, 2; moderately reduced uptake, 3 ; severely reduced uptake, and 4 ; no 
uptake) $(9,14,15)$. If there was reduction of count in only one segment thinking of us attenuation artifact, the score was accepted as 0 (16).

A common semiquantitative analysis of SPECT images were performed visually and provided pixel based analysis automatically by gamma camera software. Polar maps are graphic displays of sets of circumferential profiles of the short-axis slices. It can provide semiquantitative analysis regarding the extent and severity of perfusion defect. The size of the defect is expressed as a percentage of the area without uptake in relation to the total area of the projection $(6,15,17)$.

Two independent experienced observers blindly evaluated the reconstructed images, the polar maps and the $3 \mathrm{D}$ images of rest-redistribution studies. In the case of discordance between the two observers, the view of a third observer was requested and the disagreement was resolved by consensus. Summed redistribution scores (SRS) were obtained by adding the scores of the segments of redistribution images.

\section{Coronary angiography and coronary intervention}

Conventional coronary angiography was performed in multiple projections with AXIOM ArtisdFC (Siemens, Germany) equipment. Immediately after diagnostic angiography, $\mathrm{PCl}$ was performed using standard material. The Thrombolysis In Myocardial Infarction (TIMI) flow in the infarct related artery before and after coronary angioplasty was graded visually by consensus of two blinded experienced authors. TIMI grade 3 coronary flow in the treated vessel with a residual stenosis $<20 \%$ was considered indicative of successful angioplasty. These patients were provided TIMI 3 flow in the infarct related coronary artery (18). Patients who not achieved TIMI 3 flow were not included in this study. On admission, all patients received clopidogrel $(300 \mathrm{mg})$ and heparin (10.000 IU). During the hospital stay and follow-up, patients received a conventional treatment including $\beta$-blockers, aspirin, clopidogrel, antihyperlipidemic and angiotensin converting enzyme inhibitors.

\section{Statistical analysis}

Statistical Package for Social Sciences software (SPSS 12, Chicago, IL, USA) was used for analysis. Normal distribution of continuous variables were analyzed with Kolmogorow Smirnov test and histogram graphics. Normally distributed continuous variables were presented as mean $\pm \mathrm{SD}$; abnormally distributed ones were presented as median (minimum-maximum). When comparing normally distributed continuous variables in dependent groups, paired samples $T$ test was used. Wilcoxon rank sign test was used if variables were abnormally distributed. Pearson and Spearmen correlation was used for testing the strength of linear relationship between continuous variables. Categorical variables were presented as number and percent. McNemar test was used when categorical variables comparing in dependent groups. A p value less than 0.05 was considered as significant.

\section{Results}

\section{Baseline characteristics}

In current study, there were 30 patients with the mean age of $52 \pm 12$ years old. Ten $(33 \%)$ patients had hypertension, $16(53 \%)$ had a family history of coronary artery disease, $14(47 \%)$ were diabetic and $23(77 \%)$ were current smokers. Mean values of body mass index, high-density lipoprotein, low-density lipoprotein, triglyceride, and total cholesterol were $26.9 \pm 3.3 \mathrm{~kg} / \mathrm{m}^{2}$, $39.5 \pm 5.9 \mathrm{mg} / \mathrm{dL}, 125.1 \pm 29.2 \mathrm{mg} / \mathrm{dL}, 138.4 \pm 52.2 \mathrm{mg} / \mathrm{dL}$, and $190.4 \pm 34.4 \mathrm{mg} / \mathrm{dL}$, respectively. The median time interval between the onset of the event and primary PCl was 67.5 minutes (20-180). Mean value of heart rate was $81 \pm 12$ (beat/minute); median values for peak CKMB and peak troponin I were 200 IU/L (65-532), $22.8 \mathrm{ng} / \mathrm{mL}$ (8-100), respectively (Table 1).

All patients underwent coronary angiography on admission and $\mathrm{PCl}$ was a total obstruction of the proximal part of the first diagonal branch of left anterior descending artery (TIMI-0). 25 of 30 patients performed $\mathrm{PCl}$ and coronary stent placement, 3 patients direct stent placement, 2 patients just $\mathrm{PCl}$ due to long lesion and unsuitable size of stents. However, the day after that, stent placement was also done by obtaining appropriate stent. 8 of 30 patients had plaque in the left circumflex and 9 in the right coronary artery. During the hospital stay and follow-up of patients, reocclusion and reinfarction were not seen.

\section{Effects of $\mathrm{PCl}$ on ventricular remodeling}

Left ventricular functions were improved at two months after $\mathrm{PCl}$ according to baseline values that were obtained by echocardiography and scintigraphy. Mean EDV values for baseline and two months later were $116 \pm 15$ and $106 \pm 12 \mathrm{~mL}(\mathrm{p}<0.001)$;

Table 1. Characteristics of the patients $(n=30)$

\begin{tabular}{|l|c|}
\hline Age, years & $52 \pm 12$ \\
\hline Female gender, $\mathrm{n}, \%$ & $4(13.3 \%)$ \\
\hline History of hypertension, $\mathrm{n}, \%$ & $10(33 \%)$ \\
\hline Family history of CAD, $\mathrm{n}, \%$ & $14(47(\%)$ \\
\hline History of type 2 diabetes mellitus, $\mathrm{n}, \%$ & $23(77 \%)$ \\
\hline $\mathrm{BMI}, \mathrm{kg} / \mathrm{m}^{2}$ & $26.9 \pm 3.3$ \\
\hline $\mathrm{HDL}, \mathrm{mg} / \mathrm{dL}$ & $39.5 \pm 5.9$ \\
\hline $\mathrm{LDL}, \mathrm{mg} / \mathrm{dL}$ & $125.1 \pm 29.2$ \\
\hline $\mathrm{TG}, \mathrm{mg} / \mathrm{dL}$ & $138.4 \pm 52.2$ \\
\hline Cholesterol, mg/dL & $190.4 \pm 34.4$ \\
\hline \begin{tabular}{l} 
Duration from event to PCI, minutes \\
\hline Heart rate, beatlminute
\end{tabular} & $67.5(20-180)$ \\
\hline $\begin{array}{l}\text { CKMB, IU/L } \\
\text { Troponin-l, ng/mL }\end{array}$ & $81 \pm 12$ \\
\hline $\begin{array}{l}\text { Data are presented as mean } \pm \mathrm{SD}, \text { median (minimum-maximum), and as proportion } \\
\text { (percentage) } \\
\text { BMI - body mass index, CAD - coronary artery disease, CKMB - creatine kinase MB } \\
\text { fraction, HDL - high-density lipoprotein, LDL - low-density lipoprotein, TG - triglyceride }\end{array}$ \\
\hline
\end{tabular}


mean ESV were $61 \pm 12$ and $52 \pm 10 \mathrm{~mL}(\mathrm{p}<0.001)$; mean EF were $48 \pm 8$ and $52 \pm 7 \%(p<0.001)$; median SRS were $8.5(0-24)$ and 5 $(0-18)(p<0.001)$; median Polar maps were $69.5(0-99)$ and 50 $(0-90) \%(p<0.001)$ (Table 2, Fig. 1-3). The majority $(76.7 \%)$ of patients had an $\mathrm{EF} \geq 50 \%$ and only $23.3 \%$ experienced a critically low $\mathrm{EF} \leq 50 \%$ two months after the event. This shows 10 (33\%) patients' EFs were improved over $50 \%(\mathrm{p}=0.002)$ (Table 2). In our study mean EDV and ESV are improved as statistically significant except in the $3^{\text {rd }}$ and $6^{\text {th }}$ patients, respectively

There was not any marked change in SRS in five patients. Of these patients, there hasn't been any change in their second images because of elongated myocardial stunning in two of them, and because of silent AMI dependent on diabetes in three of them.

Polar maps were correlated with heart rate $(r=0.438 ; p=0.023$; Fig. 4), peak CKMB ( $r=0.440 ; p=0.015$; Fig. 5) and troponin-I $(r=0.471 ; p=0.009$ Fig. 6$)$ level during acute MI. Peak CKMB and

Table 2. Comparison of left ventricular function values between baseline (after PCI) and after two months

\begin{tabular}{|l|c|c|c|}
\hline Variables & Baseline after PTCA & Two months later & ${ }^{*} \mathrm{p}$ \\
\hline EDV, $\mathrm{mm}^{3}$ & $116 \pm 15$ & $106 \pm 12$ & $<0.001$ \\
\hline $\mathrm{ESV}, \mathrm{mm}^{3}$ & $61 \pm 12$ & $52 \pm 10$ & $<0.001$ \\
\hline $\mathrm{EF} \%$ & $48 \pm 8$ & $52 \pm 7$ & $<0.001$ \\
\hline SRS & $8.5(0-24)$ & $5(0-18)$ & $<0.001$ \\
\hline Polar maps, $\%$ & $69.5(0-99)$ & $50(0-90)$ & $<0.001$ \\
\hline
\end{tabular}

Data are presented as mean \pm SD and median (minimum-maximum)

*Paired samples T test or Wilcoxon rank sign test EDV - end-diastolic volume, EF - ejection fraction, ESV - end-systolic volume, $\mathrm{PCI}$ - percutaneous coronary intervention, SRS - summed redistribution score, polar maps

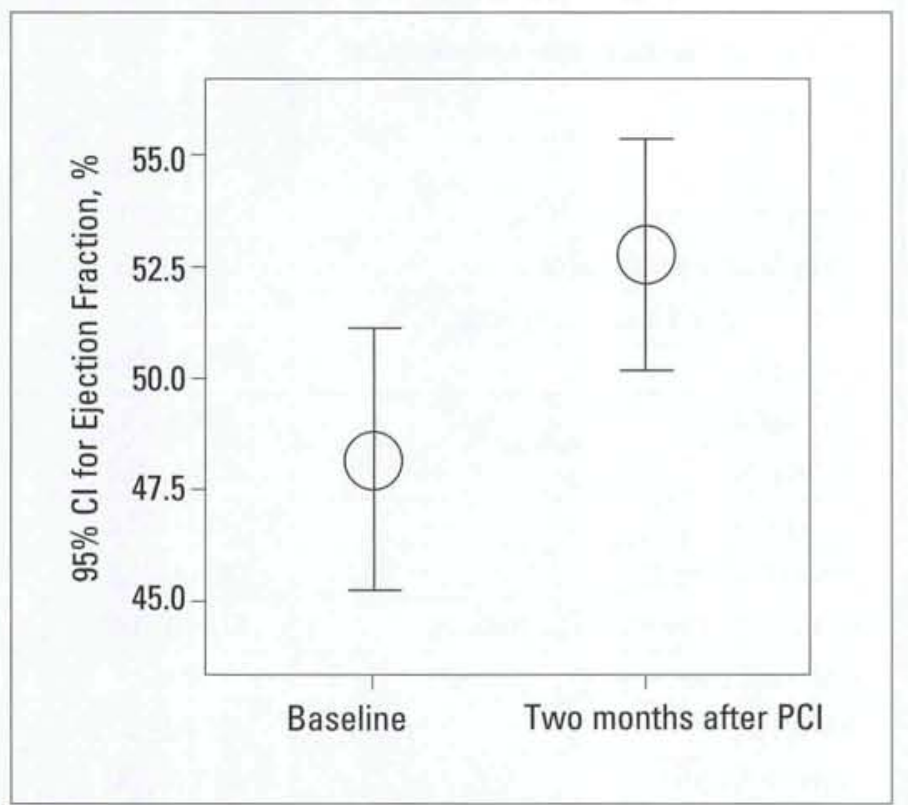

Figure 1. Error bars with $95 \%$ confidence interval show the effect of remodeling on the mean ejection fraction within two months. Paired samples t test $(\mathrm{p}<0.001)$

$\mathrm{PCl}$ - percutaneous coronary intervention
EF values at baseline $(r=-0.510 ; p=0.004)$ and two months after the event $(r=-0.538 ; p=0.002)$ were also correlated.

\section{Discussion}

There was a significant recovery of $L V$ function during the first two months after an anterior $\mathrm{AMI}$ treated with $\mathrm{PCl}$. Reduction in perfusion defect of the magnitude of $1 \%$ of the LV mass may be functionally important for LV function improvement and a marker of positive LV remodeling in general (12). As in the other studies, we also found that the initial size of perfusion defect was correlated with both end-diastolic volume and LV ejection fraction after 2 months $(12,19,20)$. Observed improvement in perfusion on MPS two months later, presided independently to the improvement in the LV function. We claim that the amount of myocardium remodeling by reperfusion therapy is an important predictor of the improvement of the LV function as well.

Byrne et al. (21) and Doğan et al. (22) have reported that peak troponin $T$ and creatine kinase were demonstrated to have similar moderate correlation with scintigraphic infarct size. Our results revealed peak troponin I and creatine kinase values were correlated with SRS and polar maps were in agreement with this study. Similarly, Akashi et al. (23) has been reported that the washout rate of Tc99m-sestamibi was also significantly correlated with the peak creatine kinase $(r=0.34, p=0.012)$ and reflected the extent of myocardial damage in AMI patients. Busk et al. (24) has studied final infarct size and myocardial salvage early presenters $(<12 \mathrm{~h})$ vs. late presenters $(12-72 \mathrm{~h})$ undergoing primary angioplasty. They found that late presenters undergoing primary angioplasty had a larger final infarct size and a lower salvage index when compared with early presenters. In the

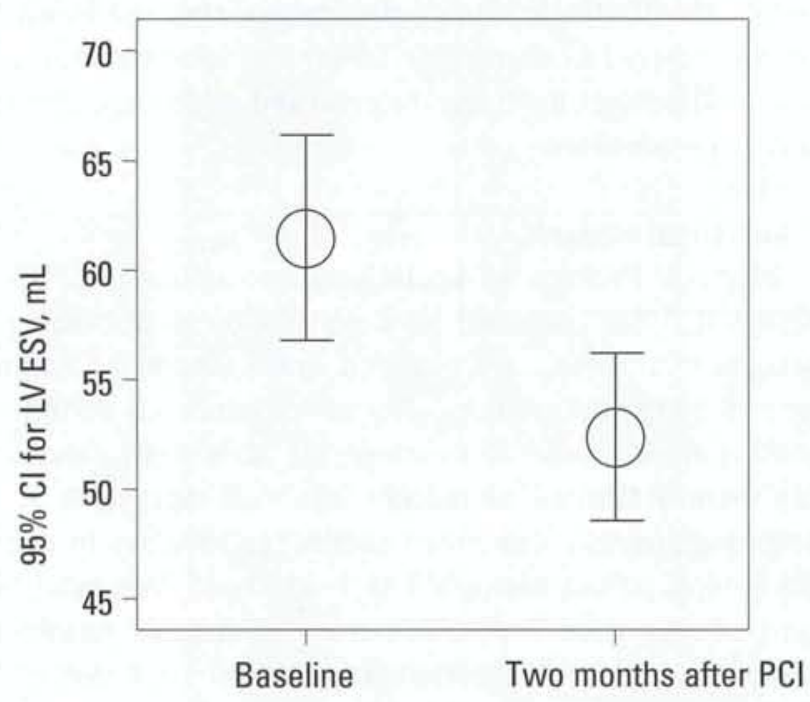

Figure 2. Error bars with $95 \%$ confidence interval show the effect of remodeling on the mean LVESV within two months. Paired samples $t$ test $(p<0.001)$

LVESV - left ventricular end-systolic volume, $\mathrm{PCl}$ - percutaneous coronary intervention 


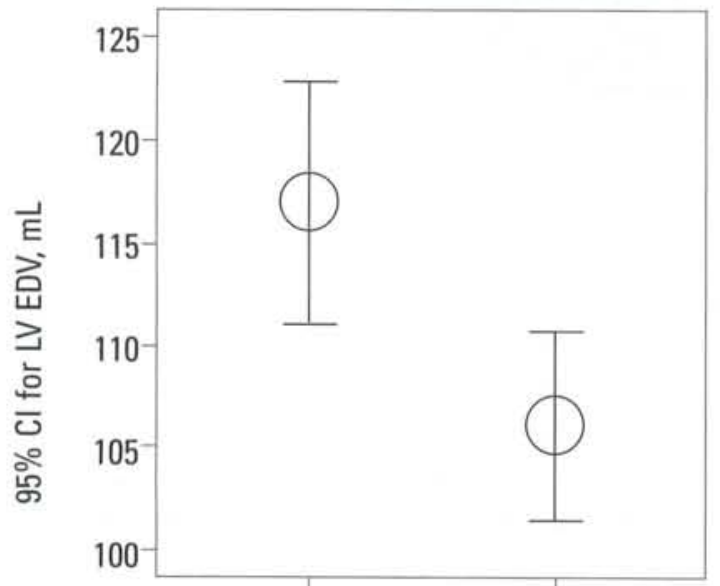

Baseline Two months after $\mathrm{PCI}$

Figure 3. Error bars with $95 \%$ confidence interval show that effect of remodeling on the mean LVEDV within two months. Paired samples $t$ test $(p<0.001)$

LVEDV - left ventricular end-diastolic volume, $\mathrm{PCI}$ - percutaneous coronary intervention

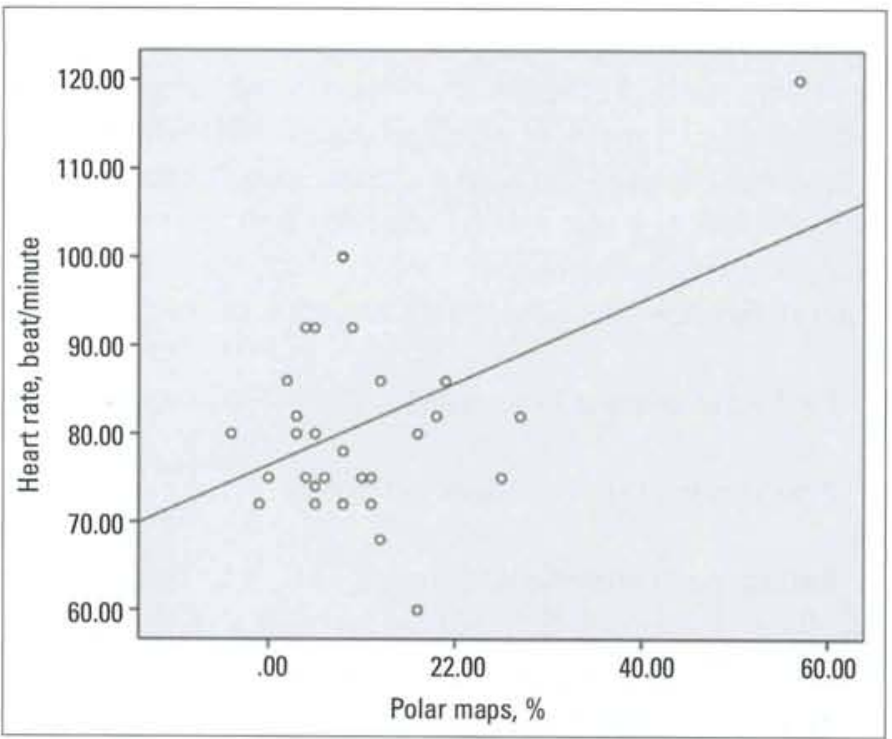

Figure 4. Correlation between heart rate and polar maps. Spearman correlation analysis: $r=0.438 ; p=0.023$

present study, we evaluated myocardial salvage early presenters $(<6 \mathrm{~h})$ undergoing primary angioplasty. Late presenters were not included in this study.

Zellweger et al. (9) had similar findings with us. They reported that improvement was most obvious in patients with a significant stenosis in left anterior descending artery and in those with a moderate to large extent of ischemia (sum differential score (SDS) $\geq 5$ ); in their patients, EDV and ESV improved significantly after $\mathrm{PCl}$, whereas these changes were smaller and not significant in patients with a small extent of ischemia (SDS $\leq 5$ ). Our findings indicated that the change in SRS after primary $\mathrm{PCl}$

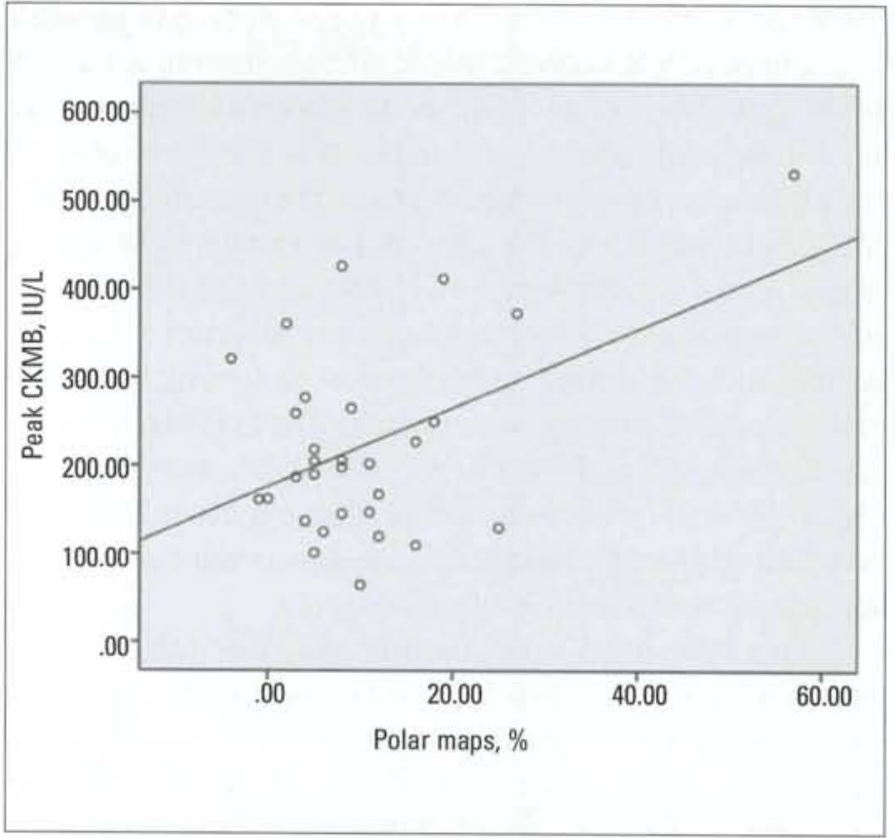

Figure 5. Correlation between peak CKMB and polar maps. Spearman correlation analysis: $r=0.440 ; p=0.015$

CKMB- creatine kinase MB fraction

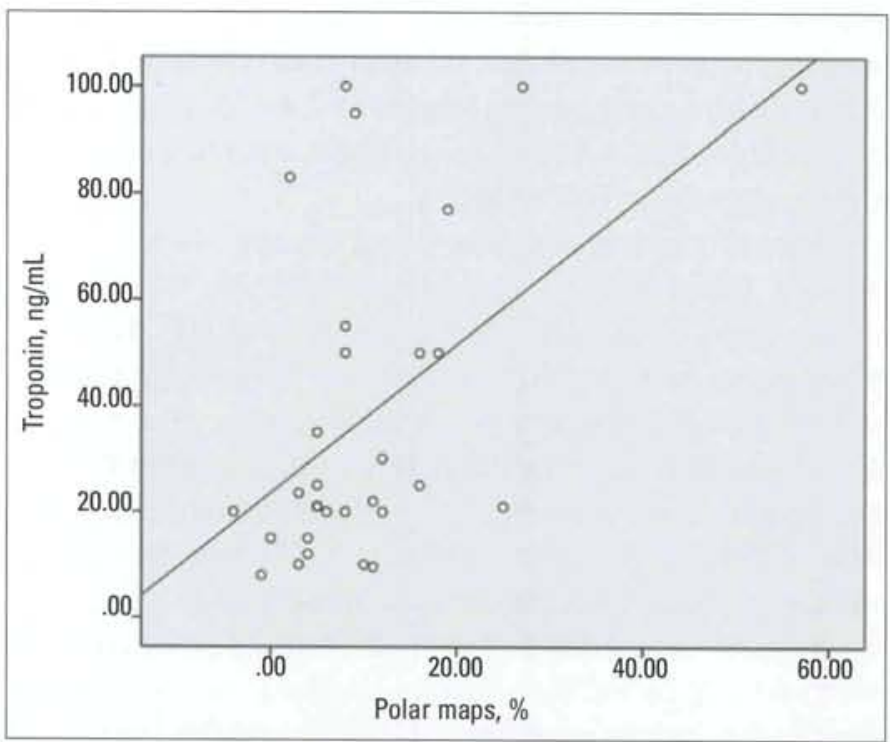

Figure 6. Correlation between troponin and polar maps. Spearman correlation analysis: $r=0.471 ; p=0.009$

was $<4$ in 20 patients, $>4$ in 5 patients. The reason of the multiplicity of the number of patients having SRS $<4$ is performing primary angioplasty within 6 hours after the beginning of symptoms. Early primary angioplasty is an advantage in providing more myocardial salvage extent.

There were significant changes in left ventricular volumes. Two months after PCl, a significant decrease in ESV and EDV was detected which points to a positive effect on left ventricular remodeling with or without a significant change in EF. Araszkiewicz et al. (10) noted that increase in the EDV $\geq 20 \%$ between day 3 and 6 months was considered as a significant 
predictor of adverse LV remodeling. In our study, EDV and ESV values have significantly decreased when compared to the values two months before, except in $3^{\text {rd }}$ and $6^{\text {th }}$ patients, respectively. This finding shows that most of remodeling procedure is completed within two months. However, they reported that $30 \%$ of patients treated with $\mathrm{PCl}$ after $\mathrm{MI}$ had restenosis in infarctrelated artery at the time of the 6-month follow-up, which might lead to impairment in LV performance and adverse LV remodeling (10). In order to avoid occurrence of restenosis, we determined the follow-up time as two months. The majority $(76.7 \%)$ of our patients had an EF $\geq 50 \%$ and only $23.3 \%$ experienced a critically low $E F \leq 50 \%$ two months after the event, reflecting best medical practice, rapid hospital diagnosis, optimal revascularization techniques and medical therapy.

On the other hand, tissue Doppler and strain rate echocardiography have been used for determining the left ventricular contractility and vitality and its superiority to conventional echocardiography methods was shown $(25,26)$. In the study of Aksakal et al. (26), as in current study, it was indicated that, after successful $\mathrm{PCl}$, important left ventricular echocardiographic parameters were recovered. We planned to conduct our study via (with) conventional echocardiography method, since tissue Doppler and strain echocardiography was not available in our hospital in that period of time. Aksakal et al. (26) have reported that strain/strain rate imaging have been used for determination of myocardial deformation changes and parameters of viability and compared with Tl-201 imaging.

In patients treated with reperfusion therapy, infarct size was reduced. Reperfusion not only limits infarct size, but also preserves viable myocardium in the infarct zone (11). However, there was no marked change in SRS in our five patients. Delayed performance of angioplasty due to diabetes which may mask the symptoms and this can be the reason for the result in three of these patients. For the other two patients, prolonged stunning effect may be the reason of no change in SRS two months after primary angioplasty according to our opinion.

It has been reported that vascular stunning in the region of infarction may persist for weeks to months after restoration of blood flow by balloon angioplasty (12). This reversible impairment of left ventricular function has been demonstrated especially in patients with anterior infarction. Revascularization may cause a reversal of hibernation and stunning. Gradual recuperation of the microvascular function improves tissue reperfusion and radionuclide uptake; and this result in further reduction in the reperfusion defect. Prolonged time course of the recuperation in the microvascular function after acute $\mathrm{AMI}$ allows us to assume that at least a part of this recuperation may occur in the weeks after second MPS imaging in the present patients. And then, there may be an inherent property of infarct size to shrink in the days to weeks after acute MI owing to edema reabsorption and phagocytosis of necrotic myocardial cells (early shrinkage) and collagen production and contraction (late shrinkage) (12).

\section{Study limitations}

The main limitation of this study is the relatively small size of the patient population because of the exclusion of patients due to unsuccessful PCI. Several functional and imaging (\&data) differences in the patients with and without LV remodeling would become statistically significant if there were larger patient population. Another limitation is use of only conventional echocardiography because not having tissue Doppler and strain echocardiography in our hospital.

Angiography was not performed at follow-up due to ethical concerns, so that patency in the infarct related artery was not verified.

Since we had no follow-up data later than 2 months, it was not possible to evaluate whether a change in LV function and imaging results were also a change associated with remodeling and prognosis. Future follow-up studies should be performed to evaluate these parameters.

\section{Conclusion}

Our results showed a significant decrease in EDV, ESV and SRS after PCl which points out a positive effect on remodeling, and furthermore showed that most of remodeling procedure is completed within two months. LV remodeling was also defined as an increase in EF 2 months after infarction when compared to baseline measurements of individual patient. Rest-redistribution TI-201 SPECT imaging just after treatment of the acute phase of an initial AMI and two months after the AMI is shown to be highly accurate for detection of myocardial salvage. Improvement in the LV function positively affects long-term survival.

Conflict of interest: None declared.

Peer-review: Externally peer-reviewed.

Authorship contributions: Concept - H.U., N.Ç.; Design - H.U., N.Ç.; Supervision - H.U., S.Y., N.Ç.; Resource - H.U., S.H.; MaterialN.Ç., N.S., S.Ö.; Data collection\&/or Processing - H.U., S.H.; Analysis \&/or interpretation - H.U., M.E.E., N.Ç.; Literature search- H.U., N.Ç.; Writing - H.U.; Critical review - H.U., N.Ç., S.0̈.; Other - H.U., N.Ç.

\section{References}

1. Bolognese L, Neskovic AN, Parodi G, Cerisano G, Buonamici P, Santoro GM, et al. Left ventricular remodeling after primary coronary angioplasty patterns of left ventricular dilation and longterm prognostic implications. Circulation 2002; 106: 2351-7.

2. Lipiecki J, Cachin F, Durel N, Tauriac 0, Ponsonnaille J, Maublant J. Influence of infarct-zone viability detected by rest Tc- $99 \mathrm{~m}$ sestamibi gated SPECT on left ventricular remodeling after acute myocardial infarction treated by percutaneous transluminal coronary angioplasty in the acute phase. J Nucl Cardiol 2004; 11: 673-81. 
3. Beller GA, Heede RC. SPECT imaging for detecting coronary artery disease and determining prognosis by noninvasive assessment of myocardial perfusion and myocardial viability. J Cardiovasc Transl Res 2001; 4: 416-24.

4. Petrasinovic Z, Ostojic M, Beleslin B, Pavlovic S, Sobic-Saranovic D, Djordjevic-Dikic A, et al. Prognostic value of myocardial viability determined by a 201TI SPECT study in patients with previous myocardial infarction and mild-to-moderate myocardial dysfunction. Nucl Med Commun 2003; 24: 175-81.

5. Kula M, Tutuş A, Abacı A, Oğuzhan A, Arslan SM, Ergin A. Comparison between rest technetium-99m-tetrofosmin and restredistribution thallium-201 SPECT in stable patients with healed myocardial infarction. Nucl Med Commun 2001; 22: 1317-24.

6. Sciagra R, Sestini S, Bolognese L, Cerisano G, Buonamici P, Pupi A. Comparison of dobutamine echocardiography and $99 \mathrm{mTc}$ sestamibi tomography for prediction of left ventricular ejection fraction outcome after acute myocardial infarction treated with successful primary coronary angioplasty. J Nucl Med 2002:43:8-14.

7. Demirkol MO. Myocardial viability testing in patients with severe left ventricular dysfunction by SPECT and PET. Anadolu Kardiyol Derg 2008; 8 Suppl 2: 60-70.

8. He YM, Yang XJ, Wu YW, Zhang B. Twenty-four-hour thallium-201 imaging enhances the detection of myocardialischemia and viability after myocardial infarction: a comparison study with echocardiography follow-up. Clin Nucl Med 2009; 34: 65-9.

9. Zellweger MJ, Tabacek G, Zutter AW, Weinbacher M, Cron TA, Müller-Brand J, et al. Evidence for left ventricular remodeling after percutaneous coronary intervention; Effect of percutaneous coronary intervention on left ventricular ejection fraction and volumes. Int J Cardiol 2004; 96: 197-201.

10. Araszkiewicz A, Lesiak M, Grajek S, Prech M, Cieslinski A. Relationship between tissue reperfusion and postinfarction left ventricular remodeling in patients with anterior wall myocardial infarction treated with primary coronary angioplasty. Kardiol Pol 2006; 64: 383-8.

11. Ottervanger JP, Hof AWJV, Reiffers S, Hoorntje JCA, Suryapranata $\mathrm{H}$, Boer MJ, et al. Long-term recovery of left ventricular function after primary angioplasty for acute myocardial infarction. Eur Heart J 2001; 22: 785-90.

12. Ndrepepa G, Mehilli J, Martinoff S, Schwaiger M, Schömig A, Kastrati A. Evolution of left ventricular ejection fraction and its relationship to infarct size after acute myocardial infarction. J Am Coll Cardiol 2007; 50: 149-56.

13. Munk K, Andersen NH, Schmidt MR, Nielsen SS, Terkelsen CJ, Sloth $E$, et al. Remote ischemic conditioning in patients with myocardial infarction treated with primary angioplasty; Impact on left ventricular function assessed by comprehensive echocardiography and gated single-photon emission CT. Circ Cardiovasc Imaging 2010; 3: 656-62.

14. Cerqueira MD, Weissman NJ, Dilsizian V, Jacobs AK, Kaul S, Laskey WK, et al. Standardized myocardial segmentation and nomenclature for tomographic imaging of the heart: a statement for healthcare professionals from the cardiac imaging committee of the council on clinical cardiology of the American Heart Association. J Nucl Med 2002; 9: 240-5.

15. Doğan I, Sönmez B, Karaman K, Çelik S, Türker 0. Optimal positioning in the detection of inferior wall infarct size with myocardial perfusion scintigraphy: prone vs. supine. Anadolu Kardiyol Derg 2010; 10: 539-43.

16. Georgoulias P, Tzavara C, Demakopoulos N, Giannakou S, Valotassiou V, Tsougos I, et al. Incremental prognostic value of $99 \mathrm{mTc}$-tetrofosmin myocardial SPECT after percutaneous coronary intervention. Ann Nucl Med 2008; 22: 899-909.

17. Castro PF, Corbalan R, Baeza R, Nazzal C, Greig DP, Miranda FP, et al. Effect of primary coronary angioplasty on left ventricular function and myocardial perfusionas determined by Tc-99m sestamibi scintigraphy. Am J Cardiol 2001; 87: 1181-4.

18. Poli A, Fetiveau R, Vandoni P, del Rosso G, D'Urbano M, Seveso G, et al. Integrated analysis of myocardial blush and STsegment elevation recovery after successful primary angioplasty: Realtime grading of microvascular reperfusion and prediction of early and late recovery of left ventricular function. Circulation 2002; 106: $313-8$.

19. Kaltoft A, Bottcher M, Sand NPR, Nielsen TT, Rehling M. Electrocardiographic gated $99 \mathrm{mTc}$-sestamibi SPECT immediately after primary percutaneous coronary intervention characterizes reperfusion success. Cardiology 2003; 99: 198-204.

20. Leoncini M, Bellandi F, Sciagra R, Maioli M, Toso A, Sestini S, et al. Use of $99 \mathrm{~m} \mathrm{Tc}$-sestamibi gated SPECT to assess the influence of anterograde flow before primary coronary angioplasty on tissue salvage and functional recovery in acute myocardial infarction. Eur $\mathrm{J}$ Nucl Med Mol Imaging 2004; 31: 1378-85.

21. Byrne RA, Ndrepepa G, Braun S, Tiroch K, Mehilli J, Schulz S, et al. Peak cardiac troponin-T level, scintigraphic myocardial infarct size and one-year prognosis in patients undergoing primary percutaneous coronary intervention for acute myocardial infarction. Am J Cardiol 2010; 106: 1212-7.

22. Akashi YJ, Ashikaga K, Takano M, Izumo M, Ishibashi Y, Kida K, et al. Significance of $99 \mathrm{mTc}$-sestamibi myocardial scintigraphy after percutaneous coronary intervention in patients with acute myocardial infarction. Med Sci Monit 2011; 17: CR140-5.

23. Busk M, Kaltoft A, Nielsen SS, Bottcher M, Rehling M, Thuesen L, et al. Infarct size and myocardial salvage after primary angioplasty in patients presenting with symptoms for $<12 \mathrm{~h}$ vs. $12-72 \mathrm{~h}$. Eur Heart Jour 2009; 30: 1322-30.

24. Voigt JU, Flachskampf FA. Strain and strain rate. New and clinically relevant echo parameters of regional myocardial function. Z Kardiol 2004; 93: 249-58.

25. Smiseth OA, Stoylen A, Ihlen H. Tissue Doppler imaging for the diagnosis of coronary artery disease. Curr Opin Cardiol 2004; 19: 421-9.

26. Aksakal E, Gürlertop Y, Seven B, Sevimli S, Gündoğdu F, Arslan S, et al. Assessment of the regional myocardial deformation changes and viability in anterior acute myocardial infarction patients by strain and strain rate imaging. Anadolu Kardiyol Derg 2010; 10: 479-87. 
Copyright of Anatolian Journal of Cardiology / Anadolu Kardiyoloji Dergisi is the property of Aves Yayincilik Ltd. STI and its content may not be copied or emailed to multiple sites or posted to a listserv without the copyright holder's express written permission. However, users may print, download, or email articles for individual use. 